doch als PR-Instrument für die Unternehmen weitgehend an Bedeutung verlieren, wenn es nicht gelingt, durch neue Konzepte dem Thema jeweils Nachrichtenwert zu verleihen. Dabei fällt der Blick in erster Linie auf die vergleichende Quantifizierbarkeit der betrieblichen Umweltleistungen. Wenn überhaupt Chancen auf eine systematische, einzelfallübergreifende Debatte über die unternehmerische Umweltpolitik bestehen, dann durch leicht verständliche Betriebs- und Branchenvergleiche. Hier trifft sich zudem das öffentliche Interesse mit dem der ökologischen Pionierunternehmen.

\section{Perspektiven der Umweltkommunikation}

Es ist offensichtlich, daß die Veröffentlichung von Umwelterklärungen allein zunehmend weniger Aufmerksamkeit gewinnen wird. Sollte die Teilnahme an der EU-Verordnung in Deutschland erfolgreich diffundieren, dann wird die Zahl der Berichte in kurzer Zeit die Verarbeitungskapazität der kritischen Öffentlichkeit wie die der Medien übersteigen.

Eine Möglichkeit, Umwelterklärungen handlungswirksamer werden zu lassen, wäre die Einrichtung eines überbetrieblichen Informations-

1) Besonders prägnant diskutiert bei Marx, T.G., Strategic Planning for Public Affairs, in: Long-RangePlanning, Nr. 1/1990, S. 9 - 16

2) Vgl. Pfriem, R., Unternehmenspolitik in sozialökologischen Perspektiven, Marburg 1995, S. 336

3) Vgl. Kraemer, A., Die EG-Öko-Audit-Verordnung und ihr Umfeld in der Europäischen Umweltpolitik, in: Fichter, K. (Hg.), EG-Öko-Audit-Verordnung, Mit Öko-Controlling zum zertifizierten Umweltmanagementsystem, SR 81/95 des IÖW

4) Vgl. 2, 4 Abs. 3, 4 a-e der 9. Verordnung zur Durchführung des Bundesimmissionsschutzgesetzes (Verordnung über das Genehmigungsverfahren vom 29.03.1992 (BGBI. I S. 1001), 2, 3 der Verordnung über das Verfahren bei der Genehmigung von Anlagen nach $\$ 7$ des Atomgesetzes (Atomrechtliche Verfahrensverordnung -AtVfV) i.d.F. d. Bek. vom 03.02.1995 (BGBI. I, S. 180)

5) Anhang III Abschn. B. 4. EU-Ökoaudit-Verordnung

6) Vgl. bspw. Leffson, U., Die Grundsätze ordnungs- kreises zur Durchführung eines ökologischen Betriebsvergleichs. Auf freiwilliger Basis und unter Leitung eines umweltpolitisch ausgewiesenen Dritten, der für die Glaubwürdigkeit und die fachliche Integrität des Systems verantwortlich wäre, könnten sich Unternehmen zu einem »Reduktionsclub « zusammenschließen. Aufgaben könnten die Diskussion über betriebliche Umweltschutzziele, der Erfahrungsaustausch und schließlich die Durchführung von Betriebs- und Branchenvergleichen sein. Die Ergebnisse sollten durch offensive PR-Arbeit bekanntgemacht werden.

Die alternative Lösung, ein Ranking in Anlehnung an die »Top 500 Polluters « beim TRI in den USA, wäre wohl nur die zweitbeste Variante. Es ist zu erwarten, daß für externe Beobachter die Bewertung der betrieblichen Umweltdaten immer lückenhaft bleiben wird. Erinnert sei nur an Faktoren wie: Veränderungen der Fertigungstiefe (Out- oder Insourcing), des Auslastungsgrades, Produktinnovationen usw. Gleichwohl rechtfertigt das berechtigte öffentliche Interesse am Umwelthandeln der Betriebe auch vereinfachende Vergleiche.

Neben dieser Medienorientierung scheinen die größten Chancen der Umweltberichterstattung

mäßiger Buchführung, 7. Aufl., Düsseldorf 1987

7) Vgl. Förschle, G. / Mandler, U., Umwelterklärung, Umweltgutachter und Wirtschaftsprüfung, in: BFuP 6/1994, S. 524 f.

8) Vgl. Art. 4 Abs. 5) d) EU-Ökoaudit-Verordnung

9) Art. 5 Abs. 2 EU-Ökoaudit-Verordung

10) Art. 3. Pkt. a) EU-Ökoaudit-Verordnung

11) Vgl. Förderkreis Umwelt future e. V. (Hrsg.), Umweltberichte -Umwelterklärungen, Hinweise zur Erstellung und Verbreitung, Osnabrück 1994, S. 17 ff. 12) Art. 5 Abs. 3 EU-Ökoaudit-Verordnung

13) Vgl. Beck, U., Risikogesellschaft, Frankfurt a. M. 1986, S. 70

14) Vgl. Coenenberg, A. G. et al., Unternehmenspolitik und Umweltschutz, in: ZfbF, Nr. 1/1994, S. 97 und Haßler, R., Öko-Rating - Ökologische Unternehmensbewertung als neues Informationsinstrument, Schriftenreihe zur ökologischen Kommunikation, Bd. 2, München 1994, S. 4

15) Meffert, H., Kirchgeorg, M., Der Einfluß von Ökologie und Marketing auf die Strategien, in: asw, in der Anlieger- und Mitarbeiterkommunikation zu liegen. Gerade für die Auseindersetzung mit den Anwohnern bedarf es jedoch weit mehr als der Veröffentlichung von Umwelterklärungen. Hier müssen von den Unternehmen Formen entwickelt und Anlässe iniiert werden, die das Interesse an umweltpolitischen Fortschritten immer wieder neu aktivieren. Nach allen bisher vorliegenden Praxiserfahrungen kommt den Beschäftigten beim Umwelt-Audit vornehmlich eine passive, auf die Befolgung von Verfahrensanweisungen kaprizierte Funktion zu. Die Erfahrungen der betriebswirtschaftlichen Organisationstheorie wie auch zahlreiche Fallstudien aus der Unternehmenspraxis verweisen jedoch darauf, daß ein Umweltmanagement als (alleiniger) Top-Down-Prozeß nur geringe Erfolgsaussichten aufweist. Arbeitnehmer und Management vor Ort wissen immer noch am besten, ob die heren Umwelterfolge, die in der $\mathrm{Er}$ klärung ausgelobt werden, freiwillige Umweltleistungen, Gratiseffekte betrieblicher Umstrukturierungen oder Ergebnis gesetzgeberischen Handelns sind.

Silke Hermann, Achim Spiller Eschborn

Sonderheft 10/1990, S. 42 und Schülein, J. A. et al., Manager und Ökologie, Opladen 1994, S. 187

16) Vgl. den Überblick bei Staab, J. F., Nachrichtenwert-Theorie, München 1990

17) Vgl. Schmitt-Beck, R., Über die Bedeutung der Massenmedien für soziale Bewegungen, in: Kölner Zeitschrift für Soziologie und Sozialpsychologie, $\mathrm{Nr}$. 4/1990, S. 649 f.

18) Vgl. Wiedemann, P. M., Krisenkommunikation, 2. Aufl., Eschborn 1993, S. 37

19) Vgl. auch Ruhrmann, G., Risikokommunikation, in: Publizistik, Nr. 1/1992, S. 12

20) Vgl. auch Kepplinger, H. M., Weißbecker, H., Negativität als Nachrichtenideologie, in: Publizistik, Nr. $3 / 1991$, S. $330-342$

21) Vgl. Krämer, A., Ökologie und politische Öffentlichkeit, München 1986, S. 221

22) Vgl. Luhmann, N., Soziologische Aufklärung 5 Opladen 1990, S. 178 f.

23) Vgl. Marcinkowski, F., Publizistik als autopoietisches System, Opladen 1993, S. 105

\title{
Encouraging Improvements in Environmental Reporting - the Role of Award Schemes
}

\begin{abstract}
Award schemes can play an important role in encouraging better corporate environmental and financial reporting. The environmental reporting award scheme described below is administered by the Chartered Association of Certified Accountants (ACCA), a United Kingdom accountancy body which is active in the field of environmental accounting research.
\end{abstract}

1994 was the fourth year of the annual Environmental Reporting Award Scheme (ERAS) sponsored by the Chartered Association of Certified Accountants (ACCA). The judges reported that greater clarity of focus and better environmental information systems have produced a steady improvement in the quality of company enyironmental reporting since 1991 when the award scheme was initiated. This had led to an increasing quality in reports submitted.

The role which award schemes can play in encouraging better corporate behaviour (be it financial reporting or environmental management) has long been recognised. In the UK there are awards for the best public company set of financial statements, the best small company accounts, the best charity accounts, even the best accounts issued by a local authority. Similarly there are any number of awards recognising out- standing performance in the areas of environmental management. The underlying purpose is always the same - to encourage better reporting and to reward innovation. The ACCA Environmental Reporting Award scheme has a similar objective: »to stimulate and reward initiatives in environmental reporting ". The scheme is open to companies and public sector bodies throughout the European Union and covers both standalone environmental reports and environmental reporting through the medium of the annual corporate report. However, we are really only competent to deal with reports published in English although we did make efforts to translate one Dutch language and one German language entry for the 1994 scheme.

The ACCA environmental initiative has been given a warm reception in other countries. By the end of 1995 similar schemes will be running 
in Canada, Holland and Denmark. In addition the Instituut fur Okologische Wirtschaftsforschung (IÖW) has carried out a »ranking « exercise of German environmental reports (see below) and an environmental reporting category seems to have appeared as part of the annual Italian »accounting Oscars $\ll$.

Winners of the ACCA awards to date include some of the UKs leading corporates plus some leading non-UK companies (see table 1):

\section{- Band A: basic minima}

1. Environmental Policies: (or reference to ICC, CEFIC, PERI, Responsible Care, identification of target audience)

2. Management (commitment / -systems): (reference to environmental audits, reviews, EMAS, 7750 etc: management systems and structure)

3. Narrative (impact of core business(es)): the value of understandability

\begin{tabular}{|lll}
\hline \multicolumn{2}{|l}{ Table $1:$} & Winners of the ACCA awards \\
1991 & Joint winners & NORSK HYDRO \& BRITISH AIRWAYS (»BA «) \\
\hline 1992 & Winner & BRITISH TELECOMMUNICATIONS (»BT $«)$ \\
& Commendations & BA \& BODYSHOP INTERNATIONAL \\
\hline 1993 & Winner & BT \\
& Commendations & BRITISH GAS \& BRITISH PETROLEUM (»BP $)$ \\
& Best first time reporter & THORN EMI \\
\hline 1994 & Winner & THORN EMI \\
& Commendations & BP \& BT \& DOW EUROPE \\
& Best first time reporter & \& DET DANSKE STALVALSEVAERK \\
& ROHM \& HAAS EUROPE
\end{tabular}

The 1994 ERAS received 37 environmental reporting entries from 36 companies and 1 noncommercial organisation. 16 entries were received from outside the UK. The 21 UK entries represented about $50 \%$ of UK companies issuing stand alone environmental reports in the year to 31 July 1994 . The inclusion of non-UK reports (for the first time) gave a different perspective on environmental reporting. In general, non-UK reporting placed greater emphasis on the inclusion of health and safety factors, a greater systems-based approach leading to wider use of oköbilanz plus a greater awareness of energy issues.

In 1995 we would like to encourage entries from small and medium sized enterprises. Identifying these companies is however a major problem.

\section{The Criteria \\ Applied By the Judges}

In the four years since the scheme began, the panel of judges has remained fairly consistent. the panel has included

- environmental consultants,

- the government environment ministry,

- environmental accounting academics,

- the accountancy standard setting body,

- the green investment industry,

- the Confederation of British Industry,

- trades union representatives.

Despite the variation in their backgrounds the panel have shown remarkable similarity in their choice of outstanding environmental reports. They have deliberately chosen NOT to adopt a quantitative »ranking « approach (but see below) and instead have evolved a qualitative set of criteria. These are set out below:

\section{- Band B: quantitative disclosures}

4. Factual data (good + bad news): at global and/or site level

5. historical trends (+ commentary and explanations) at global and/or site level

- Band C: performance against targets 6. Targets: (again, global and/or site) preferably quantified so as to be capable of verification

7. Performance against targets

8. Explanations of variances

\section{- Band D: the financial dimension}

9. Financial linkages: financial statement links via cross-references or by inclusion of environmental data in the full financial statements or summary financial statements themselves 10. Liabilities and provisions: quantified liabilities and provisions (+ movements), accounting policies, Operating and Financial Review statements (MD\&A), risk positioning

11. Environmental expenditures: capital vs. revenue expenditure, actual and likely spends

- Band E: verification

12. External (meaningful) verification: from auditor or consultant: consider scope of examination and form of report

- Band F: beyond compliance reporting 13. Sustainability: (some discussion of sustainability and the company's attitude to it)

14. Life cycle / mass ballance / eco balance sheet: resource use, efficiency indices etc. Alternative methods of communicating the entity's environmental impact and commitments

15. Extras: (Computer discs, Internet availability, newsletters, videos etc.) do they add to/detract from/adequately substitute for - the overall environmental reporting package?
The absence of a quantitative element does not seem to have hampered the panel unduly. The range of environmental reporting techniques is so varied that the panel has, increasingly, sought to give a number of commendations in addition to the main award, in order to reflect the fact that, as things stand at present, many different companies are carrying out worthwhile experiments in environmental reporting.

\section{Comparison of the Criteria with the 1994 IÖW »Ranking » Approach}

In 1994 the IÖW carried out a survey of 50 German companies which had issued environmental reports. The researchers identified 13 main criteria and allotted weights to them. They then ranked the 50 companies according to their overall scores. The criteria and the weightings are given below.

Table 2:

IÖW reporting criteria and weightings

1. General description of the company $5 \%$

2. General information on environmental policy and environmental guidelines

3. Organisational structure of the environmental management system

4. Description of production related environmental issues

5. Description of environmental impacts of products and services

6. Analysis and evaluation of ecological problems

7. Environmental programme and objectives

8. Impact of conservationist measures on returns

9. Communication with target groups

10. Possibility of feedback for the reader

11. Credibility

12. Principles of accounting

13. Target group adequacy

The main difference between the IÖW and ACCA approaches lies in ACCAs emphasis on target setting, achievements and financial linkages, and the IÖWs focus on impacts, problems and programme objectives. These individual differences of emphasis reflect perhaps a broader conceptual difference between German and UK approaches to environmental reporting, the former being driven by ecological impact and process analysis, the latter by compliance and performance measures.

Out of a maximum of 500 points the highest score in the IÖW ranking was 375 (by Neumarkter Lammsbrau). A list of the »top 10 « is provided in table 3 (next page). 
Table 3:

The top 10 companies in the IÖW ranking exercise:

\begin{tabular}{rlr} 
Rank & \multicolumn{1}{c}{ Company } & Score/500 \\
\hline 1 & Neumarkter Lammsbrau & 375 \\
2 & Firma Gunther & 348 \\
3 & Steilmann-Gruppe & 325 \\
4 & Heidleberger Druckmaschinen & 287 \\
5 & Ludwig Stocker Hofpffisterei & 266 \\
6 & Mohndrug & 254 \\
7 & Philipp Holzmann & 251 \\
8 & Bosch-Siemens Hausgerate & 249 \\
9. & Kunert AG, Immenstadt & 248 \\
10. & Bad Brückenauer Mineral- \\
& brunnen, Siegsdorfer & \\
& Petrusquelle & 246 \\
& British Telecom & 315 \\
& Dow Europe & 304
\end{tabular}

Source: „Environmental Reporting and the EMAS-Statement in Germany «

J Clausen \& K Fichter IÖW DP 35/95

Having completed their ranking exercise the researchers asked the question $»$ is it sensible to aim at reaching the total score of 500 points when writing an environmental report? «. Like the researchers, I would prefer to avoid having to give a direct answer to that question, but it is important to appreciate that in the environmental disclosure debate there are bound to be differences of opinion and of emphasis. The merits of site-based reporting as against consolidated global reports are still being discussed. The extent to which finance and the environment can and should be integrated seems likely to remain a contentious issue. The needs of the various stake-holder groups which have been identified are unlikely to be $100 \%$ congruent.

The usefulness of independent external verifiers statements has often been disputed. Thus it may not make sense for a company to aim for 500 points in a single consolidated document unless it can be shown that the criteria listed constitute a developed and generally agreed conceptual framework - which at present of course they don't.

The results of the IÖW survey highlight the gulf between the excellent, the very good and the only average. There are 3 German companies getting $60 \%$ or more of the available points . In the current state of environmental reporting these must be classified as excellent. There is a then a small cluster of companies getting around 250 marks or $50 \%$. These one could call very good. Those getting below 200 are probable average. Companies which do not attempt environmental reporting make up, of course, the vast majority of companies.

\section{The Results of the ACCA Award Scheme}

The winning companies in the 1994 ERA scheme have already been identified. The judges comments on the individual award winners were as follows:
Danish Steel Works Ltd. This Danish company has based its "Green Accounts« on the massbalance (or ökobilanz) approach. The essence of the mass-balance is a systems perspective on the flow-through of materials and energy that the organisation experiences in a cycle of production. The »Green Accounts« are published within the body of the company's Annual Report and are accompanied by additional data, information on policies and targets for 1994. The ökobilanz methodology is developing rapidly in parts of Europe and the next step, for a report like that of Danish Steel, is developing more explicit links with the financial side of the organisation.

British Telecom and Dow Europe It is difficult not to be impressed by the effort, care and thought that has gone into the preparation of, what are now, very substantial documents. These reports are pleasantly laid out, easy to read and give a substantial image of the companies' environmental progress. The reports are especially valuable for the way in which they develop from previous years' reports whilst providing the reader with a sense of the consistency of the company's approach. Dow's report stands out for its attestation. The report actually carries two independent attestation statements, both of which specify that they have reached their conclusions on the basis of systems audits with compliance testing. BT stand out for its very clear use of life-cycle assessment and, particularly, its reporting of environmental performance against targets.

$B P$ 's 1993 environmental reporting package is extensive. It comprises a significant amount of data in the Annual Report, a Health, Safety and Environment (HSE) Report, a digest of data in booklet form - »facts 1993 « - and a computer disc of information. There is little question that $\mathrm{BP}$ has made major strides in integrating the environment into its financial reporting cycle. Not only are environmental issues mentioned in the Annual Report in 6 different places but the company gives an extensive analysis of the financial dimensions of its environmental response.

Rohm and Haas Reflecting both the experience gained by other reporting companies as well as the company's own responses to the chemical industry's initiatives in environmental reporting, the Rohm and Haas report is an especially clear, systematic and communicative document. It specifies its stakeholders, the company's environmental policy, targets and programmes and includes, in addition to site-level emissions data, detail on environmental expenditure and prosecutions during the year. This willingness to report less-than-good news is evident throughout the report and, in the judges' view this, plus the systematic clarity, go some way towards balancing the lack of any attestation or any mention of sustainability.

Thorn EMI The 1994 Environmental Report from Thorn EMI was a particularly thoughtful and thorough entry to the 1994 ERAS. The report hangs around two key elements: life-cycle assessment of each segment of the business and reporting and discussion of environmental performance targets. The report systematically reviews the segments of the business, focuses on the key issues and progressively develops its targets. At least part of this clarity seems to come from the systematic use of life-cycle assessment. The report also is independently attested, reports a significant amount of financial data and expresses intelligent and thoughtful views on the compatibility of business practice and sustainability.

\section{Conclusions}

Most of the companies identified as worthy of commendation by the ACCA judges or ranked $250+$ by the IÖW researchers would classify as being in the Stage 3 / Stage 4 classification of corporate environmental reporting (Elkington/UNEP 》Company Environmental Reporting « $1994 \mathrm{P}$ 18). Companies will not automatically pass through to Stage 5 (»sustainable development reporting «) simply by amassing more points on the IÖW ranking (say $400+$ ) nor by fulfilling more of the ACCA criteria more fully. To reach Stage 5 a real shift in reporting must occur, reflecting the real changes which must have occurred within the reporting entity to make sustainable operations a possibility/reality.

The judges of the ACCA scheme concluded that those companies which had entered were still in a small vanguard of innovating, reporting companies. Mistakes and successes were being borne on a voluntary basis whilst the bulk of industry was happy enough to let them get on with it. When, the judges asked, will environmental reporting be made mandatory? In their view, as long as such reporting is voluntary it will remain a minority activity. They believe that the leading companies - as well as society at large - had a right to expect some regulation in this area. Also, how are the accounting requirements of the EU's Fifth Action Plan, Towards sustainability, to be met? They could see no evidence to suggest that accounting within conventional frameworks for liabilities and provisions will make any appreciable difference to a company's sustainability. They looked forward seeing governments and accounting professions offering more substantial support for environmental and sustainability accounting and reporting.

Short of legislation at the EU level comparable to the 4th Company Law Directive, there is no one single way of ensuring that all companies across Europe start disclosing relevant, timely, comparable environmental data. Award schemes and ranking exercises such as those described above play a part in spreading ideas and rewarding the adventurous. They provide a focus for discussion and debate and should assist both preparers and stake-holder groups by illustrating the range of approaches which, at any given moment, are said to constitute »best practice«. They can, however, only reflect (and only marginally influence) what is happening in the mar- 
(c) 20I0 Authors; licensee IÖW and oekom verlag. This is an article distributed under the terms of the Creative Commons Attribution Non-Commercial No Derivates License (http://creativecommons.org/licenses/by-nc-nd/3.o/), which permits unrestricted use, distribution, and reproduction in any medium, provided the original work is properly cited. 